http://dx.doi.org/10.12775/szhf.2016.005

\title{
David Hume
}

\section{O kredycie publicznym}

Wydaje się, że w starożytności podczas pokoju powszechnie dbano o rezerwy na poczet potrzeb wojennych, gromadzono także zawczasu zasoby, które mogły potem służyć jako środki do podboju lub obrony ${ }^{1}$. W ten sposób w okresach zamętu i zawirowań nie trzeba było wprowadzać nadzwyczajnych obciążeń, tym bardziej nie było konieczne sięganie po pożyczki. Wiemy nie tylko o ogromnych, wspomnianych uprzednio, sumach ${ }^{2}$, które były gromadzone przez Ateny i przez Ptolemeuszy, a także przez innych następców Aleksandra, ale od Platona ${ }^{3}$ dowiadujemy się, że również oszczędni Lacedemończycy zgromadzili znaczne skarby. Flawiusz Arrian ${ }^{4}$ i Plutarch natomiast informują o bogactwach, które zdobył Aleksander w trakcie podboju Suzy

\footnotetext{
${ }^{1}$ [Podstawa przekładu: David Hume, Of the Balance of Trade, w: tegoż, Essays, Moral, Political, and Literary, ed. Eugene F. Miller, Liberty Fund, Inc., Indianapolis 1987. Przypisy, które nie pochodzą od Hume’a, zostały ujęte w nawiasy kwadratowe; wykorzystano w nich uwagi wydawcy edycji będącej podstawą tłumaczenia].

${ }^{2}$ Esej V [wyd. polskie: D. Hume, O równowadze handlu, przeł. D. Kosiewicz-Wawrzonkowska, „Studia z Historii Filozofii”, nr 1(6)/2015, s. 27-42].

${ }^{3}$ Alkibiades I [wyd. polskie: Pseudo-Platon, Alkibiades I, 122d-123b, [w:] tenże, Alkibiades I $i$ inne dialogi oraz Definicje, przeł., wstępem i komentarzem opatrzył Leopold Regner, Warszawa 1973, s. 44-45].

${ }^{4}$ Lib. III [wyd. polskie: Flawiusz Arrian, Wyprawa Aleksandra Wielkiego, przeł. Helena Gesztoft-Gasztold; wstępem i koment. opatrzył Józef Wolski, Ossolineum-De Agostini, WrocławWarszawa 2004, s. 130-139].
} 
i Ekbatany ${ }^{5}$, a z których część była gromadzona jeszcze od czasów Cyrusa. Jeżeli dobrze pamiętam, Biblia wspomina także o skarbie Ezechiasza i książąt żydowskich ${ }^{6}$, historia świecka zaś o królach macedońskich, Filipie i Perseuszu. Starożytne republiki Galii miały w rezerwie równie znaczne sumy ${ }^{7}$. Każdy wie o skarbach zagrabionych w Rzymie przez Juliusza Cezara w czasie wojen domowych'; dowiadujemy się także, że co mądrzejsi z cesarzy, August, Tyberiusz, Wespazjan, Septymiusz Sewer i inni zawsze odznaczali się roztropną przemyślnością, oszczędzając wielkie sumy na wypadek jakichkolwiek pilnych potrzeb publicznych.

Współcześnie, przeciwnie, rozpowszechniło się sięganie po pożyczki pod zastaw dochodów państwa i pokładanie wiary w tym, że potomni spłacą ciężary podjęte przez ich przodków. Mając zaś przed oczami przykład swych mądrych ojców, będą oni równie roztropnie polegać na swoich potomkach, którzy wreszcie, raczej z konieczności niż z wyboru, będą zmuszeni pokładać takie samo zaufanie w swoich potomnych. Nie traćmy jednak czasu na wypominanie praktyk, które wydają się bezsprzecznie rujnujące; jest raczej oczywiste, że zasady, którymi kierowali się starożytni, są w tej kwestii roztropniejsze niż współczesne, nawet jeżeli te ostatnie były ograniczane rozsądnymi ramami i jeśli liczono zawsze, że gospodarność w czasie pokoju pozwoli na spłacenie długów zaciąganych na poczet drogich wojen. Dlaczego sytuacja państwa miałaby tak bardzo różnić się od sytuacji pojedynczego człowieka, abyśmy mieli ustanowić dla nich odrębne zasady postępowania? Jeżeli fundusze tych pierwszych są znaczniejsze, ich konieczne wydatki zaś proporcjonalnie większe, jeśli ich zasoby są liczniejsze, a jednak nie są nieskończone, powinny one być zatem obliczane na dużo dłuższy czas niż lata ludzkiego życia, a nawet całej rodziny. Powinno się zatem przyjmować zasady, które

\footnotetext{
${ }^{5}$ Plut. in vita Alex. Wylicza on owe skarby na 80 tys. talentów czyli około 15 milionów funtów sterlingów [Plutarch z Cheronei, Aleksander Wielki, 36, [w:] tenże, Żywoty sławnych mężów, przeł. Mieczysław Brożek, Ossolineum, Wrocław 1953, s. 222-223; dokładnie mowa jest o 40 tys. talentów w bitej monecie oraz innych kosztownościach]. Kwintus Kurcjusz (ks. V. rodz. 2.) powiada, że Aleksander znalazł w Suzie ponad 50 tys. talentów [wyd. polskie: Kwintus Kurcjusz Rufus, Historia Aleksandra Wielkiego, przekł. zbiorowy pod red. Lidii Winniczuk, Warszawa 1976, s. 15].

${ }^{6}$ [Zob. 2 Krl 18, 15; 2 Krn 32, 27-29]

7 Strabo, lib. IV.

${ }^{8}$ [Na początku wojny domowej z lat 49-45 p.n.e., która zakończyła się całkowitym zwycięstwem nad Pompejami i innymi wrogami, Juliusz Cezar przejął skarbiec państwowy Rzymu, w którym znajdowały się wielkie sumy w złotych i srebrnych sztabach oraz innych kosztownościach; zob. Plutarch z Cheronei, Cezar, 35, w: tenże, Żywoty sławnych mężów, s. 602-603].
} 
są ogólne, obliczone na długi czas, zakładane z naddatkiem i odpowiednie do przewidywanej długości ich obowiązywania. Faktem jest, że ufanie przypadkowi i przygodnym rozwiązaniom jest rzeczywiście tym, co konieczność spraw ludzkich często uznaje za nieuniknione. Jednakże ktokolwiek dobrowolnie zdaje się na takie fundusze, czyni to nie ze względu na konieczność, ale na własny kaprys, by zrzucić z siebie winę na nieszczęścia, gdy jakieś się przytrafią .

O ile nadużywanie zasobów skarbca może być niebezpieczne ze względu na angażowanie się państwa w nieprzemyślane przedsięwzięcia, czy też zaniedbywanie wojskowej dyscypliny i pokładanie zaufania $\mathrm{w}$ bogactwie, to tym bardziej pewne i nieuniknione są złe skutki nadużywania kredytu: ubóstwo, niemoc i podległość zewnętrznym mocarstwom.

Dziś już wiemy, że wojna wiąże się ze wszelkimi destrukcyjnymi okolicznościami: utratą ludzi, wzrostem podatków, upadkiem handlu, rozproszeniem pieniędzy, zniszczeniami na lądzie i morzu. Zgodnie z dawnymi zasadami, otwieranie skarbu publicznego, które powodowało niezwykły dopływ złota i srebra, służyło jako tymczasowa zachęta dla przemysłu i, do pewnego stopnia, rekompensowała nieuniknione straty wojenne. Sięganie po takie środki stanowi wielką pokusę dla urzędnika państwowego, gdyż w okresie, gdy sprawuje on swój urząd, umożliwiają mu one obracanie wielkimi kwotami, bez obciążania przy tym ludzi nadmiernymi podatkami i wystawiania się na głosy oburzenia. Dlatego też każdy rząd w sposób wręcz nieunikniony będzie zaciągał długi. Udzielenie politykowi upoważnienia do wydawania pieniędzy na rachunek swych potomnych jest jednak niemal tak samo nierozważne, jak udzielenie przez każdego londyńskiego bankiera kredytu synowi marnotrawnemu.

Cóż zatem mamy powiedzieć na ów nowy paradoks, polegający na tym, że niezależnie od tego, iż zaciąganie długów publicznych jest koniecznością,

\footnotetext{
${ }^{9}$ [Rozważania Hume’a przedstawione w tym eseju powinno się analizować w kontekście osiemnastowiecznych dyskusji dotyczących tego, czy dług publiczny jest korzystny czy szkodliwy. Francuski ekonomista Jean-François Melon (1675-1738, autor Essai politique sur le commerce, 1754), podobnie jak niektórzy Brytyjczycy, argumentował, że dług publiczny zapewnia środki dla ciała politycznego lub że wzbogaca naród, jednak większość brytyjskich myślicieli, łącznie z Humem i Adamem Smithem, była zaniepokojona wzrastającym długiem publicznym (Patrz: Shutaro T. Matsushita, The Economic Effects of Public Debts, Nowy Jork 1929, rozdział 1). W Badaniach nad natura i przyczynami bogactwa narodów Smith przedstawiał argumentację podobną do tej z eseju Hume’a, jednak bardziej szczegółową (wyd. polskie w przekł. Stefana Wolffa i in., Warszawa 2007, t. II, ks. V, rozdz. 3, s. 605-656)].
} 
one same miałyby przynosić korzyść, i że każde państwo, nawet jeśli nie podlega presji ze strony wroga zewnętrznego, rzekomo nie mogłoby znaleźć mądrzejszego sposobu wspierania handlu i własnych bogactw, niż nieograniczone tworzenie funduszy, zaciąganie długów i nakładanie podatków? Tego rodzaju rozumowanie mogłoby uchodzić za retoryczną sztuczkę, jak panegiryki chwalące głupotę lub szaleństwo Buzyrysa ${ }^{10}$ czy Nerona, gdybyśmy nie widzieli, że owym niedorzecznym maksymom patronują wielcy ministrowie $^{11}$, a także cała partia w naszym kraju.

Zbadajmy, jakie skutki mają długi publiczne, jeśli idzie o politykę wewnętrzną, jaki jest ich wpływ na handel i przemysł oraz na sprawy zagraniczne, a także jakie jest ich znaczenie dla wojen i negocjacji.

Publiczne weksle skarbowe (public securities) stały się u nas swego rodzaju pieniądzem, handluje się nimi po aktualnej cenie tak samo jak złotem i srebrem. Wszędzie, gdzie pojawia się jakieś zyskowne przedsięwzięcie, niezależnie jak kosztowne by nie było, nigdy nie brak rąk, które by chciały się go chwycić; także handlarz, który ma znaczne sumy ulokowane w akcjach publicznych, może bez obawy zająć się nawet najbardziej ryzykownym handlem, skoro posiada fundusze, po które może sięgnąć nawet w najbardziej

${ }^{10}$ [Buzyrys - według greckich podań legendarny król Egiptu, syn Posejdona i egipskiej księżniczki Lizjanassy, miał składać Zeusowi ofiary z cudzoziemców po to, aby zapobiec klęsce głodu].

${ }^{11}$ [Fragment ten jest poświęcony przede wszystkim krytyce sir Roberta Walpole’a, który odgrywał wiodącą rolę w Izbie Gmin od momentu wyboru w 1701 roku, aż do rezygnacji popierających go wigów oraz jego samego z funkcji pierwszego ministra w 1742 roku. Zamiar Huméa jest nieco jaśniejszy we fragmencie opuszczonym w tej wersji eseju; został niemal dosłownie sparafrazowany przez Smitha: „By zapobiec temu zgiełkowi, sir Robert Walpole pragnął wykazać, że dług publiczny nie jest niedogodnością, chociaż można założyć, że człowiek o jego zdolnościach sam dostrzegał tu niespójność" (A. Smith, Lectures on Jurisprudence, Indianapolis 1982, s. 515). W 1717 roku Walpole przyczynił się do ustanowienia funduszu amortyzacyjnego, by uwolnić skarb główny od długu publicznego; polityka ta w następnej dekadzie odniosła przynajmniej częściowy sukces. Jednak w 1733 roku Walpole nalegał, by Parlament przeniósł środki z funduszu amortyzacyjnego, by sprostać bieżącym wydatkom, argumentując, że to będzie mniejsze obciążenie dla kraju niż podniesienie podatku od ziemi. Takiemu obrotowi spraw sprzeciwiali się ci, którzy postrzegali fundusz amortyzacyjny jako „święte błogosławieństwo” i ,jedyną nadzieję państwa”. W czasie kolejnych lat pełnienia przez Walpolea funkcji ministra regularnie wycofywano pieniądze $\mathrm{z}$ funduszu amortyzacyjnego (Patrz: Norris A. Brisco, The Economic Policy of Robert Walpole, Nowy Jork 1967, rozdział 2). Hume sugeruje w tym fragmencie, że uzasadnienie Walpole’a dla kontynuowania zadłużenia jest w oczywisty sposób wadliwe, skoro chwali tyranów (Buzyrys, zgodnie z mitologią grecką, był okrutnym władcą Egiptu) i inne godne potępienia rzeczy]. 
nagłej potrzebie. Żaden kupiec nie uważa za konieczne trzymania przy sobie znacznej ilości gotówki. Akcje bankowe, a także zobowiązania indyjskie ${ }^{12}$, zwłaszcza te drugie, wszystkie służą tym samym celom, ponieważ można nimi dysponować lub w ciągu kwadransa zastawić je u bankiera. Nie leżą one jednak bezczynnie, nawet jeśli tkwią w sekretarzyku kupca, lecz przynoszą stały dochód. Krótko mówiąc, nasze długi państwowe dostarczają kupcom tego rodzaju pieniądza, który nieustannie pomnaża się w ich rękach, dając pewne zyski, niezależnie od dochodów z ich działalności handlowej. Pozwalają one na czerpanie mniejszych zysków z handlu, a mały zysk kupca oznacza, że towary są tańsze, konsumpcja rośnie, a zwykli ludzie bardziej ochoczo pracują. Dzięki nim cała społeczność może też czerpać korzyści ze sztuk i rzemiosł.

Zauważmy również, że w Anglii i wszelkich innych państwach, w których handlowi towarzyszy możliwość zaciągania długu publicznego, istnieje pewna grupa osób, które są na poły kupcami, na poły zaś udziałowcami, i które zadowalają się handlem przynoszącym niewielkie zyski, albowiem działalność handlowa nie stanowi dla nich jedynego ani nawet zasadniczego źródła zarobku, a dochody, które dają im udziały w funduszach, są dla nich i dla ich rodzin pewnym źródłem utrzymania. Gdyby nie istniały żadne fundusze, wielcy kupcy chcąc osiągnąć choćby część swych zysków lub je zabezpieczyć, musieliby nabywać ziemię. To rozwiązanie $\mathrm{w}$ porównaniu $\mathrm{z}$ funduszami ma jednak wiele wad. Ziemia wymaga większej troski i częstszego doglądania, zajmuje czas i uwagę kupca, a gdy pojawia się jakaś kusząca propozycja lub nadzwyczaj okazyjna transakcja, nie tak łatwo jest ją spieniężyć. Ponieważ ziemia jest aż nazbyt pociągająca, zarówno ze względu na naturalne przyjemności, jakie oferuje, jak i szacunek, którym cieszy się jej właściciel, szybko zmienia zwykłego obywatela w ziemianina. Dlatego też należy oczekiwać, że tam, gdzie istnieje możliwość zaciągania długu publicznego, więcej ludzi o dużych zasobach i wysokich dochodach będzie zajmować się działalnością handlową. To zaś, trzeba przyznać, przynosi pewną korzyść samemu handlowi, zmniejszając zyski, wspomagając obieg pieniądza i wspierając przemysł.

Jednak w przeciwieństwie do tych dwóch korzystnych okoliczności, zapewne o niezbyt znacznej wadze, należy rozważyć wiele wad, które wiążą się $\mathrm{z}$ naszym długiem publicznym w zakresie całej wewnętrznej gospodarki pań-

12 [Hume ma prawdopodobnie na myśli akcje brytyjskiej kompanii wschodnioindyjskiej założonej w 1600 roku i stanowiącej podstawę polityki imperialnej Wielkiej Brytanii]. 
stwa: zauważyć można, że zło, które z niego wynika, jest nieporównywalnie większe niż dobro.

Po pi e r w s ze, jest pewne, że dług narodowy powoduje potężny napływ ludzi i bogactw do stolicy. Powodem są duże sumy z podatków nałożonych po to, aby spłacić od niego odsetki, a być może także wspomniane wcześniej udogodnienia w handlu, które stawiają kupców posiadających kapitał w stolicy na pozycji dogodniejszej niż tych, którzy mieszkają poza nią. Pytanie jednak brzmi, czy w omawianym tu przypadku jest korzystne dla interesu publicznego, by tak wiele przywilejów nadawać Londynowi, który i tak już rozrósł się do ogromnych rozmiarów i nadal się powiększa. Niektórzy już teraz dostrzegają konsekwencje tego faktu. Jeśli chodzi o mnie, nie mogę nie zauważać, że chociaż głowa naszego kraju jest bez wątpienia zbyt rozrośnięta w stosunku do ciała, to owo wspaniałe miasto jest w dodatku tak szczęśliwie ulokowane, że jego nadmierny rozrost sprawia mniej niewygód niż mniejsza stolica większemu królestwu. Większa jest różnica w cenach wszelkich dóbr między Paryżem a Langwedocją niż między Londynem a hrabstwem York. Wszelako ogrom Londynu, którego rządy nie opierają się na władzy arbitralnej, sprawia, że ludzie stają się wichrzycielscy, niepokorni, wywrotowi, a nawet skorzy do buntu. Jednak na tę szkodliwość długu publicznego on sam wynajduje lekarstwo. Pierwszy widoczny wybuch niepokojów społecznych, a nawet bezpośrednie nim zagrożenie, musi zaalarmować posiadaczy, których własność jest obciążona największym ryzykiem. Wówczas udadzą się oni po wsparcie rządu, pod groźbą czy to przemocy ze strony jakobitów ${ }^{13}$, czy szaleństwa demokratów.

Po drugi e, emitowane papiery dłużne, będąc rodzajem kredytu, mają wszystkie wady dotykające tego rodzaju środki. Wypierają złoto i srebro z najważniejszych gałęzi handlu państwowego, kierując je jedynie do obiegu codziennego oraz sprawiając, że zarówno wszystkie towary, jak i praca drożeją, co nie zdarzyłoby się w innej sytuacji.

Po trze cie, podatki, które są nakładane, by spłacić odsetki od tych długów, mogą albo podnieść cenę pracy, albo stać się uciążliwe dla ludzi biedniejszych.

${ }^{13}$ [Po Rewolucji Chwalebnej 1688-1789 jakobici byli zwolennikami powrotu na tron Stuartów. Powstanie jakobickie z 1715 roku miało przywrócić koronę Jakubowi Edwardowi Stuartowi, „staremu pretendentowi”, zaś powstanie z 1745 roku - Karolowi Edwarowi Stuartowi, „młodemu pretendentowi”. Nastroje jakobickie były szczególnie silne na Pogórzu Szkockim]. 
Po czwarte, gdy cudzoziemcy posiadają znaczny udział w funduszach narodowych, niejako czynią państwo zależnym od nich i z czasem mogą wywołać odpływ naszych obywateli i naszego przemysłu.

Po p i ąte, większa część papierów dłużnych znajduje się zawsze w rękach próżnujących, którym dostarczają one dochodów. Tak zdobyte środki stają się wówczas znaczącą zachętą do bezużytecznego i nieaktywnego życia.

Chociaż jednak szkoda wyrządzana handlowi i przemysłowi przez nasze fundusze publiczne po zbalansowaniu wszystkiego będzie się wydawać wcale nie taka nieznaczna, w rzeczywistości jest ona wręcz trywialna w zestawieniu z przesądem, który każe nam uważać, że państwo jako ciało polityczne musi tworzyć wraz z innymi krajami pewien rodzaj społeczności i prowadzić różnorodne transakcje z pozostałymi państwami w czasie wojen i negocjacji. Oto zło w czystej postaci, pozbawione jakichkolwiek pozytywnych przymieszek, które mogłyby je zrównoważyć. Jest to zło największe i najistotniejsze.

Powiada się, że długi publiczne nie osłabiają społeczności, gdyż zaciągane są tylko w jej obrębie i powiększają własność jednych tylko w takiej mierze, w jakiej pomniejszają ją u innych. To tak, jakby ktoś przekładał pieniądze z prawej ręki do lewej, przez co nie stawałby się ani bogatszy, ani biedniejszy niż wcześniej ${ }^{14}$. Takie niedbałe rozumowanie i zwodnicze porównania zawsze ujdą płazem, jeśli wydajemy sądy niepoparte żadnymi zasadami. Zapytam: czy z samej naturze rzeczy wynika, że kraj nie może być nadmiernie obciążony podatkami, nawet jeśli panuje w nim suweren? Sama ta wątpliwość wydaje się niedorzeczna, ponieważ w każdej społeczności musi być zawsze pewna równowaga pomiędzy tymi, którzy pracują, a tymi, którzy nic nie robią. Jeśli zaś wszystkie nasze obecne podatki byłyby zastawione, czyż nie musielibyśmy wynaleźć nowych? Czyż nie byłoby możliwe, że dojdzie wówczas do sytuacji, która może zrujnować i zniszczyć państwo?

W każdym kraju znajdzie się jakaś metoda ściągania pieniędzy, łatwiejsza niż inne, odpowiednia do sposobu, w jaki żyją tam ludzie, i do używanych przez nich towarów. W Wielkiej Brytanii znaczne dochody daje akcyza na słód i piwo, ponieważ warzenie napojów słodowych i piwa to żmudne zajęcie, którego nie sposób zaprzestać, a przy tym nie są to towary absolutnie niezbędne do życia, w przypadku których podwyżka cen dotknęłaby uboższych

${ }^{14}$ [Patrz: J. F. Melon, Essai politique sur le commerce, Presses Universitaires de Caen 2012, rozdział 23: „Długi państwa to długi, które ma prawa ręka wobec lewej, które wcale nie osłabią ciała, jeśli ma ono wystarczającą ilość substancji odżywczych i wie, jak je dystrybuować (długi)", cyt. za: Shutaro T. Matsushita, The Economic Effects of Public Debts, s. 20]. 
ludzi. Jeśliby te właśnie podatki zastawiono, jakże trudno byłoby wymyśleć nowe! Cóż to za utrapienie i ruina dla biednych!

Zobowiązania nałożone na produkty konsumpcyjne są bardziej wyrównane i łatwiejsze do ściągnięcia niż te, które nałożone są na posiadłości. Cóż to byłaby za strata dla społeczeństwa, gdyby pierwsze z nich całkiem wyczerpano i musielibyśmy uciec się do podatków, które są bardziej uciążliwe! Gdyby wszyscy posiadacze ziemscy byli jedynie zarządcami gruntów publicznych, czy nie zmusiłoby ich to do stosowania wszelkich sposobów ucisku, jakich zwykle używają zarządcy, jeśli tylko brak właściciela albo zaniedbania $\mathrm{z}$ jego strony pozwalają im je ukryć?

Mało kto przyznałby, że na dług narodowy nigdy nie powinny zostać nałożone żadne ograniczenia i że społeczeństwo nie zbiedniałoby, gdyby podatek od ziemi w wysokości dwunastu czy piętnastu szylingów od każdego funta szterlinga, łącznie z całą akcyzą i cłem, zostały zastawione. W takim przypadku mielibyśmy jednak do czynienia z czymś więcej niż tylko z przeniesieniem własności z jednej ręki do drugiej. Za 500 lat potomkowie tych, którzy obecnie podróżują powozami, oraz tych, którzy teraz nimi powożą, zamienią się być może miejscami. Mimo tego wspomniane przemiany nie wpłyną na sytuację społeczeństwa. Załóżmy jednak, że społeczeństwo zostałoby kiedyś niemal doprowadzone do stanu, ku któremu zmierza z tak zdumiewającą szybkością; załóżmy, że na ziemię nałożono by podatek w wysokości osiemnastu czy dziewiętnastu szylingów za każdy funt szterling jej wartości, nigdy bowiem nie mógłby on wynosić całych dwudziestu; załóżmy, że akcyza i cło zostałyby podniesione do takiej wysokości, jaką tylko państwo mogłoby znieść bez zniszczenia handlu i przemysłu; załóżmy też, że na wszystkie te środki zostałaby nałożona wieczysta hipoteka i że inwencja oraz pomysłowość naszych ustawodawców nie znalazłaby już żadnego sposobu, aby nałożyć nowe zobowiązania, dzięki którym można by zaciągnąć nowe pożyczki. Rozważmy konsekwencje, jakie z konieczności miałyby wynikać z takiej sytuacji. Chociaż niedoskonałość wiedzy w zakresie polityki, a także ograniczoność ludzkich zdolności, sprawiają, że trudno jest przewidywać skutki sytuacji, której nigdy nie doświadczyliśmy, już teraz można dostrzec obficie rozsiane ziarna upadku, które nie ujdą uwagi nawet najbardziej niedbałego obserwatora.

W tym nienaturalnym stanie społecznym jedynymi ludźmi, którzy posiadaliby dochody wykraczające poza bezpośrednie rezultaty ich działalności, byliby właściciele akcji, którzy pobierają prawie całą rentę gruntową i czynsz z nieruchomości poza wszelkimi cłami i akcyzami. Są to ludzie pozbawieni jakichkolwiek powiązań z państwem, mogący cieszyć się swoim zyskiem 
w tej części globu, którą wybiorą na miejsce swojego zamieszkania. W naturalny sposób zaszyją się oni w stolicy albo w wielkich miastach i będą tonąć w letargu głupiego i rozpieszczonego luksusu, upadli na duchu, pozbawieni ambicji i radości. Żegnajcie wszelkie ideały szlachty, ziemiaństwa i rodziny. Weksle mogą zmieniać właścicieli w ciągu jednej chwili, a skoro są tak płynne, rzadko będą dziedziczone $\mathrm{z}$ ojca na syna przez trzy kolejne pokolenia. Nawet gdyby kiedykolwiek pozostały tak długo w posiadaniu jednej rodziny, przeniesienie ich własności nie pociąga za sobą ani dziedzicznej władzy, ani żadnego uznania dla posiadacza. Tak oto pewna grupa ludzi, którzy tworzą w państwie rodzaj niezależnej i ustanowionej ręką natury magistratury, jest zupełnie zgubiona, a każdy, kto posiada jakąś władzę, posiada ją jedynie z upoważnienia suwerena. Poza armią najemników nie pozostaje żaden sposób zapobiegania powstaniom lub ich tłumienia. Nie ma już żadnego doraźnego środka pozwalającego na oparcie się tyranii: wyborami rządzą łapówki i korupcja, kiedy zaś władza pośrednia pomiędzy królem a ludem zostaje zupełnie zlikwidowana, niezawodnie musi wziąć górę ciężki despotyzm. Posiadacze ziemscy, wzgardzani ze względu na swe ubóstwo i znienawidzeni za stosowne przez siebie opresje, będą w pełni niezdolni do jakiegokolwiek sprzeciwu wobec niego.

Chociaż rozwiązanie proponowane przez prawodawców powinno zakładać, by nigdy nie narzucać żadnego podatku, który uderzałby w handel i zniechęcał do wytwórczości, to jest niemożliwe, aby w kwestiach wymagających tak niezwykłej delikatności ludzie rozumowali tak słusznie, że nigdy nie pomyliliby się, albo żeby trudności, jakie napotkają, nie były na tyle duże, by nie kusiły ich do zmiany podjętych postanowień. Ciągłe fluktuacje w handlu wymagają nieustannych poprawek charakteru podatków, co w każdej chwili naraża prawodawców na ryzyko świadomego lub przypadkowego błędu. Każde znaczące uderzenie w handel, czy to poprzez nieroztropne podatki, czy przypadkowe okoliczności, wprowadza zamieszanie w całym systemie rządów.

Jaki jednak środek może w takiej sytuacji zastosować społeczeństwo, nawet przy założeniu, że handel będzie nieustająco rozkwitał, by stanowić źródło finansowania zagranicznych wojen i przedsięwzięć, a także obrony honoru i interesów własnych oraz sprzymierzeńców? Nie pytam, w jaki sposób społeczeństwo ma starać się o tak kolosalną władzę, jaką utrzymywało w czasie naszych dawnych wojen, gdy tak bardzo przekroczyliśmy nie tylko nasze naturalne możliwości, lecz nawet te dostępne największym imperiom. Owa rozrzutność jest nadużyciem, na które się żalimy, jako na źródło 
wszelkich zagrożeń, na które jesteśmy teraz narażeni. Jednak skoro mamy przyjąć, że silny handel i bogactwo utrzymają się nawet wówczas, gdy każdy fundusz zostanie zastawiony, to będzie to oznaczało, że bogactwa takie muszą być bronione przez proporcjonalnie duże siły. Skąd zatem społeczeństwo ma zdobyć środki na utrzymanie tych sił? Środki te w oczywisty sposób muszą pochodzić $z$ ciągłego opodatkowania posiadaczy renty gruntowej lub, co jest w zasadzie tym samym, z zastawiania na nowo, przy każdej nagłej konieczności, określonej części rent ${ }^{15}$. W ten sposób zmusza się ich do dokładania się do kosztów obrony zarówno ich samych, jak i państwa. Jednakże trudności, które napotyka ten system gospodarowania, łatwo wyjdą na jaw, bez względu na to, czy założymy, że król stanie się władcą absolutnym, czy też że będzie wciąż kontrolowany przez rady krajowe, w których sami pobierający rentę muszą z konieczności mieć największe wpływy.

Jeśli władca zyska władzę absolutną, czego można by w naturalny sposób oczekiwać, gdyby sprawy potoczyły się w powyższy sposób, łatwo mógłby podnieść wysokość środków ściąganych od osób pobierających rentę gruntową, czego efektem byłoby jedynie zatrzymywanie przez niego pieniędzy we własnych rękach. Ten rodzaj posiadłości wkrótce straciłby cały swój kredyt, a całkowity dochód każdego człowieka w państwie musiałby z konieczności zależeć wyłącznie od łaski suwerena: po tak despotyczną władzę nigdy nie sięgnął nawet żaden wschodni monarcha. Jeśli jednak, przeciwnie, każde nałożenie podatków wymagałoby wspólnej zgody wszystkich otrzymujących rentę gruntową, wówczas nigdy nie zgodziliby się oni na sumę, dzięki której można by utrzymać rząd, ponieważ pomniejszenie ich dochodów musiałoby wówczas być bardzo znaczne, gdyby nie przyjęło pozorów jakiegoś rodzaju akcyzy czy cła, i nie było ściągane tylko od tej grupy osób, która nie jest jeszcze w najwyższym stopniu obciążona podatkami. Przykładowo, w niektórych republikach na utrzymanie państwa daje się jedną setną pensa, a czasami jedną pięćdziesiątą, zawsze jednak jest to wyjątkowe wykorzystywanie władzy, które nigdy nie stanie się stałą podstawą obrony kraju. Tam, gdzie rząd zastawił wszystkie swoje dochody, tam zawsze można dostrzec, że stacza się w ospałość, bezczynność i niemoc.

${ }^{15}$ [Adam Smith opisuje kilka rodzajów pożyczek stosowanych przez rząd brytyjski w osiemnastym wieku. Należały do nich renta wieczysta równa procentowi, który rząd mógł umorzyć w dowolnym momencie, spłacając główną pożyczoną sumę. Ten sposób zbierania środków znany był jako stałe finansowanie. Inne rodzaje renty rocznej to renty terminowe i renty dożywotnie, patrz: A. Smith, Badania nad natura i przyczynami bogactwa narodów, tamże]. 
Oto jakie są dające się racjonalnie przewidzieć niedogodności sytuacji, ku której najwyraźniej zmierza Wielka Brytania, nie wspominając o niezliczonych niedogodnościach, których nie sposób przewidzieć, a które muszą wynikać z potwornej sytuacji, w której ze społeczeństwa czyni się głównego, czy wręcz jedynego zarządcę ziemi, a oprócz tego nakłada się na nią każdy rodzaj ceł i akcyzy, jaką tylko płodna wyobraźnia urzędników i ustawodawców zdolna jest wymyśleć.

Muszę wyznać, że jeśli chodzi o długi publiczne, za sprawą długiego nawyku we wszystkich ludzi wkradła się dziwna gnuśność; niewiele różni się ona od bierności, która dotyczy kwestii religijnych, na którą tak zajadle narzekają księża. Wszyscy przyznamy, że nawet najbardziej optymistyczna wyobraźnia nie może pozwolić nam na nadzieję, że jakikolwiek obecny czy przyszły urzędnik będzie na tyle sumiennie i nieprzerwanie gospodarny, że spłaci znaczącą część naszych długów, ani że pozwoli na to sytuacja międzynarodowa, która da nam potrzebny do tego długotrwały spokój i wytchnienie. Cóż jednak wówczas by nas spotkało? Obyśmy kiedykolwiek byli na tyle dobrymi chrześcijanami i na tyle zawierzyli Opatrzności! Cóż to jednak za dziwaczne pytanie, nawet jeśli uznamy je za czysto spekulatywne, na które moglibyśmy udzielić jakiejś, choćby tylko opartej na domysłach, odpowiedzi! Otóż wydarzenia w niewielkim stopniu zależałyby wówczas od przygodnych bitew, negocjacji, intryg i podziałów. Wydaje się, że rzeczy rozwijałyby się w sposób naturalny, mogący stanowić wskazówkę dla naszego rozumowania. Chociaż zaciąganie długów wymaga jedynie zwykłej, umiarkowanej roztropności, gdy już się rozpocznie, to znając naturę tak zwykłych ludzi, jak i urzędników, moglibyśmy przewidywać, że rzeczy z konieczności potoczą się tak, że znaleźlibyśmy się w takiej samej sytuacji jak teraz. A skoro raz się ją już szczęśliwie osiągnie, nie jest trudno zgadnąć, jakie byłyby tego konsekwencje. Musiałaby zdarzyć się jedna z dwóch rzeczy: albo kraj musiałby zniszczyć kredyt publiczny, albo też kredyt publiczny musiałby zniszczyć państwo. Nie jest możliwe, aby współistniały one $\mathrm{w}$ sposób, $\mathrm{w}$ jaki do tej pory zarządzano nimi zarówno w tym, jak i w niektórych innych krajach.

Ponad trzydzieści lat temu powstał plan spłacania naszych długów zaproponowany przez wybitnego obywatela, pana Hutchinsona ${ }^{16}$; plan ten zyskał aprobatę wielu rozsądnych ludzi, jednak nigdy nie przybliżono się do jego realizacji. Hutchinson postulował, że jest swoistym oszustwem wyobrażanie

${ }^{16}$ [Archibald Hutcheson, A Collection of Treatises relating to the National Debts and Funds, London 1721]. 
sobie, iż dług ten spoczywa na społeczeństwie, skoro w rzeczywistości każdy jego członek obciążony jest proporcjonalną jego częścią, a w swych podatkach spłaca odpowiednią część odsetek, a także kosztów pobierania tych podatków. Czy nie lepiej byłoby zatem, jak twierdził, rozdzielić dług pomiędzy nas, a wówczas każdy mógłby zapłacić sumę odpowiednią do swego stanu posiadania i w ten sposób spłacić od razu całe nasze publiczne zadłużenie?

Wydaje się jednak, że nie wziął on pod uwagę tego, że pracująca biedota płaci znaczącą część podatków w swojej rocznej konsumpcji, chociaż nie mogliby oni z góry, za jednym razem, zapłacić wymaganej od nich proporcjonalnej sumy, nie wspominając o tym, że posiadane pieniądze i akcje mogą być łatwo ukryte i zamaskowane, a widoczna własność ziemi i domów w rzeczywistości odpowiadałaby za całość: oznaczałoby to nierówność i ucisk, na który nikt nigdy by się nie zgodził. Chociaż jest mało prawdopodobne, by ten projekt kiedykolwiek zrealizowano, nie jest czymś zupełnie nieprawdopodobnym, że gdy państwo będzie się dusić własnymi długami i będzie przez nie okrutnie uciskane, jakiś śmiały ustawodawca przedstawi wizjonerski plan spłacenia długów. Ponieważ zaś do tego czasu kredyt publiczny stanie się dość kruchy, pod najlżejszym dotykiem może wówczas ulec zniszczeniu, jak we Francji okresie regencji ${ }^{17} \mathrm{i} w$ ten sposób choroba $z$ ginie wraz z jej lekarzem.

Jest jednak bardziej prawdopodobne, że to pogwałcenie narodowej ufności będzie koniecznym wynikiem wojen, porażek, nękających społeczeństwo nieszczęść, a może nawet zwycięstw i podbojów. Muszę wyznać, że kiedy widzę władców i państwa walczących i skłóconych pośród swych kredytów, funduszy i długów publicznych, zawsze przywodzi mi to na myśl okładanie się pałkami w sklepie z porcelaną. Czyż można oczekiwać, że władcy oszczędzą pewne rodzaje własności, których strata jest zgubna zarówno dla nich samych i dla ogółu, skoro są tak mało wrażliwi wobec życia i własności, które są przydatne dla wszystkich?

Poczekajmy aż nadejdzie czas (a nadejdzie on z pewnością), gdy nowe fundusze, uzyskane na potrzeby danego roku, nie znajdą pokrycia i nie zbierze się przewidywanych środków. Załóżmy, że albo skarbiec państwowy byłby wyczerpany, albo nasza ufność, która uprzednio była wystarczająca, zaczęła nas zawodzić. Przyjmijmy, że w takich warunkach państwo będzie zagrożo-

${ }^{17}$ [Okres od 1643 do 1661 roku w czasie początków panowania Ludwika XVI, kiedy odpowiedzialność za rządy nad Francją spoczywała głównie na barkach Julesa Mazarina (1602-1661), kardynała i pierwszego ministra Francji]. 
ne inwazją, że grozi mu wybuch rebelii lub właśnie nastąpił, że oddziały nie mogą być odpowiednio wyposażone ze względu na brak funduszy na płace, pożywienie oraz naprawy i że nie można sięgnąć nawet po zagraniczne subsydia. Co w takiej nagłej sytuacji musi zrobić władca czy minister? Skoro pojedynczego człowieka nie można pozbawić prawa do samozachowania, to tym bardziej nie można prawa tego pozbawić społeczności ${ }^{18}$.

Jeżeli rządzący mają $\mathrm{w}$ rękach środki do zapewnienia bezpieczeństwa, ale z nich nie korzystają, to ich szaleństwo musi być wówczas większe niż szaleństwo tych, którzy pierwsi zaciągnęli dług, a tym bardziej od tych, którzy zaufali lub wciąż ufają wekslom skarbowym. Fundusze zdobyte i obłożone zadłużeniem będą do tego czasu przynosić znaczący roczny dochód wystarczający dla obrony i bezpieczeństwa państwa. Pieniądze być może są w skarbie państwa, można więc wypłacać kwartalne odsetki: konieczność wzywa, strach popędza, rozsądek nawołuje, wzywa samo współczucie. Pieniądze zostaną natychmiast zagospodarowane na bieżące potrzeby, podlegając solennym deklaracjom, że zostaną od razu uzupełnione. Niczego więcej jednak nie potrzeba: cała konstrukcja, już chwiejna, upadnie na ziemię i pogrzebie tysiące osób. To zaś, jak sądzę, można nazwać naturalną śmiercią kredytu publicznego, gdyż zmierza on do tego tak naturalnie, jak ciało zwierzęcia do rozpadu i zaniku.

${ }^{18}$ [Pisząc o niezbywalnym prawie do samozachowania (patrz także: D. Hume, Traktat o naturze ludzkiej, ks. III, cz. 2, rozdz. 10 (wyd. polskie w przekł. Cz. Znamierowskiego, Warszawa 2005, s. 632-645), Hume przywodzi na myśl koncepcje polityczne Thomasa Hobbesa i Johna Locke’a, jak również późniejsze sformułowania, takie jak amerykańska Deklaracja Niepodległości. Generalnie Hume sprzeciwia się jednak tradycji hobbesowskiej, zaprzeczając, by pragnienie samozachowania było fundamentalnym uczuciem, przez pryzmat którego powinno się rozumieć polityczne i moralne aspekty życia ludzkiego. Wyraźnie krytykuje przedstawione przez Hobbesa i Locke’a „systemy etyczne oparte na samolubstwie” (D. Hume, Dodatek II, w: tenże, Badania dotyczące zasad moralności, przeł. Michał Filipczuk i Tomasz Tesznar, Kraków 2005, s. 100) i podkreśla, że uczucia bezinteresowne często biorą górę nad egoistycznymi. Jest prawdą, że wszystkie stworzenia, włączając w to człowieka, muszą wykonywać działania, które prowadzą do ich przetrwania (Traktat, ks. I, cz. 3, rozdz. 16, s. 260) i że "umiłowanie życia” jest jednym $z$ instynktów „z przyrodzenia tkwiących w naszych naturach” (Traktat, ks. II, cz. 3, rodz. 3, s. 492), ludzie zaś odczuwają "przyrodzony strach przed śmiercią" (D. Hume, O samobójstwie, [w:] tenże, Badania dotyczące rozumu ludzkiego, przeł. Dawid Misztal i Tomasz Sieczkowski, Kraków 2006, s. 145). Mimo to Hume poświęca temu instynktowi niewiele uwagi i nie twierdzi, że dominuje on nad innymi uczuciami. Inaczej niż Hobbes, docenia on szlachetną odwagę poświęcenia samego siebie dla innych. Przyznaje też prawo do samobójstwa, gdy życie staje się nieznośne (O samobójstwie, s. 142-144). 
Większość ludzi jest tak naiwna, że nawet pomimo gwałtownego załamania się kredytu publicznego, które niosłoby ze sobą dobrowolne bankructwo Anglii, prawdopodobnie nie trzeba byłoby długo czekać, by kredyt ten odrodził się i kwitł podobnie jak wcześniej. Obecny król Francji podczas niedawnej wojny ${ }^{19}$ pożyczał pieniądze na niższy procent, niż niegdyś czynił to jego dziad. Oprocentowanie było tak niskie, że jeśli uwzględni się różnicę naturalnej stopy procentowej w obu królestwach, zbliżało się do oprocentowania, na które pożyczek udzielał angielski Parlament.

Chociaż ludzie zwykle kierują się tym, co już widzieli, a nie tym, co zaledwie można przewidywać, niezależnie od tego, jak bardzo przewidywania te są pewne, to jednak obietnice, zapewnienia, dobre na coś widoki, a także pokusa natychmiastowych zysków, muszą mieć tak potężny na nich wpływ, że niewielu tylko zdoła mu się oprzeć. Ludzie zawsze dają się złapać na tę samą przynętę i wpadają w te same sidła ciągle odgrywanych sztuczek. Szczyty popularności i patriotyzm to wciąż szeroka droga wiodąca do władzy i tyranii, pochlebstwo - do zdrady, stałe armie - do arbitralnych rządów, a Boża chwała - do dbania księży o ich ziemskie interesy. Nawet jeśli przyznamy, że kredyt publiczny jest złem, nie należy się obawiać, że zostanie na zawsze zniszczony. W rzeczywistości człowiek roztropny udzieliłby społeczności pożyczki nie w sytuacji obecnej, lecz dopiero wówczas, gdy mógłby już wykreślić nasze dotychczasowe długi, bogaty łotr bowiem, nawet jeśli nie można zmusić go do płacenia, jest dogodnym dłużnikiem dla kogoś uczciwego tylko wtedy, gdy ten zbankrutuje. Pierwszy z nich, chcąc prowadzić swe interesy, odkryje zapewne, że w jego interesie leży spłacanie swych długów, jeśli nie są zbyt wygórowane; drugi zaś nie ma na nic wpływu. Da się tutaj zastosować prawdziwe po wsze czasy słowa Tacyta ${ }^{20}$ : Sed vulgus ad magnitudinem beneficiorum aderat: Stultissimus quisque pecuniis mercabatur: Apud sapientes cassa habebantur, quce neque dari neque accipi, salva republica, poterant. Społeczność to dłużnik, którego nikt nie może zmusić do płacenia. Jedyny sposób kontroli, jaki posiadają wierzyciele, to odsetki od istniejącego kredy-

\footnotetext{
${ }^{19}$ [Ludwik XV podczas wojny o sukcesję austriacką].

${ }^{20}$ Hist. lib. iii. [„Gmin jednak na wielkość tych dobrodziejstw był łakomy: głupcy za pieniądze je kupowali; w oczach ludzi rozumnych za nic to uchodziło, czego bez szkody dla państwa ani dać, ani przyjąć nie było można” (Tacyt, Dzieje, ks. III, 55, przeł. Seweryn Hammer, [w:] tegoż, Dzieła, Czytelnik, Warszawa 2004, s. 512). Komentarz Tacyta dotyczy wysiłków cesarza Witeljusza (15-69 n.e., panującego w roku 69), mających na celu zagwarantowanie poparcia ludu w jego nieudanej walce z Wespazjanem. Zaskakujące, że Hume uważa słowa Tacyta za „po wsze czasy prawdziwe”].
} 
tu, te jednak mogą być $\mathrm{z}$ łatwością zrównoważone, jeśli kredyt jest wysoki, a okoliczności trudne i naglące, albo kiedy kredyt jest nie do odzyskania, nie wspominając już o tym, że jakaś bieżąca konieczność często zmusza kraje, by posuwały się do kroków $\mathrm{w}$ istocie sprzecznych $\mathrm{z}$ ich interesem.

Te dwa zdarzenia, które wyobraziliśmy sobie powyżej, są zgubne, jednak nie w najwyższym stopniu. Postępując $\mathrm{w}$ ten sposób, poświęca się tysiące, aby miliony mogły żyć bezpiecznie. Nie da się jednakże uniknąć niebezpieczeństwa pojawienia się sytuacji przeciwnej, w której miliony mogą zostać na zawsze poświęcone, aby na jakiś czas zabezpieczyć tysiące ${ }^{21}$. Nasz rząd uzna być może, że dla ministra jest rzeczą trudną, a nawet niebezpieczną, posuwać się do tak desperackiego kroku, jak dobrowolne bankructwo i to nawet wówczas, gdyby cała Izba Lordów składała się z zarządców ziemskich, a jeśli przeważaliby oni także w Izbie Gmin, wówczas o żadnym z członków Parlamentu nie można byłoby powiedzieć, że w funduszach ulokował wielkie sumy. Jednakże związki pomiędzy członkami Parlamentu a zarządcami ziemskimi mogą być na tyle silne, by byli przywiązani do kredytu publicznego bardziej niż wymaga tego rozsądek, przepisy, a nawet sprawiedliwość. Być może nasi zewnętrzni wrogowie okażą się wówczas wystarczająco przenikliwi, by odkryć, że nasza sytuacja obronna jest rozpaczliwa i że nie możemy otwarcie i z podniesioną przyłbicą stawić czoła niebezpieczeństwu, choćby nieuniknionemu. Podobnie jak nasi dziadowie i ojcowie uważamy, że równowaga sił w Europie jest zbyt krucha, aby można ją było zachować bez naszej uwagi i starań. Jednak nasze dzieci, znękane walką i spętane obciążeniami, gdy spoczną w poczuciu bezpieczeństwa, zobaczą, jak ich sąsiedzi są atakowani i podbijani przez innych, aż na koniec sami, podobnie jak ich dłużnicy, znajdą się na łasce zdobywcy. To zaś można całkiem słusznie określić jako nagła śmierć publicznego kredytu.

${ }^{21}$ Słyszałem, że wyliczono, iż wszystkich wierzycieli kredytu publicznego, zarówno w kraju, jak i za granicą, było jedynie 17 tysięcy. Na podstawie tego można określić ich dochód, jednakże w przypadku bankructwa kraju w jednym momencie staliby się oni najuboższymi i najbardziej pożałowania godnymi ludźmi. Dużo lepiej ugruntowana jest godność i autorytet ziemiaństwa oraz szlachty i jeśli kiedykolwiek doszłoby do takiej skrajności, spór pomiędzy nimi byłby bardzo nierówny. Gdyby nie fakt, że tego rodzaju przepowiednie naszych ojców okazały się błędne, a kredyt publiczny trwa dłużej niżby należało rozumnie oczekiwać, można by sądzić, że zdarzyć to się może całkiem niedługo, choćby i za pół wieku. Kiedy astrologowie we Francji co roku przepowiadali śmierć Henryka IV, ten stwierdził: „W końcu będą musieli mieć rację". Dlatego też powinniśmy być bardziej ostrożni w wyznaczaniu dokładnej daty i zadowolić się stwierdzeniem, że zdarzenie takie musi kiedyś nastąpić. 
Te wydarzenia nie są bardzo od nas odległe w czasie, a rozum pozwala przewidywać je z równą pewnością, jak rozwój wszystkiego, czego zaczątki już widać. Chociaż starożytni utrzymywali, że po to, aby posiąść dar prorokowania, konieczne jest swego rodzaju boskie uniesienie czy szaleństwo, można bezpiecznie przyjąć, że aby obwieszczać tego typu proroctwa, konieczne są jedynie zdrowe zmysły i uwolnienie się spod wpływu powszechnego rozgorączkowania i złudzeń.

Przekład i opracowanie:

Adam Grzeliński

Uniwersytet Mikołaja Kopernika, Toruń, Polska grzelinski@wp.pl

Anna Markwart Uniwersytet Jagielloński, Kraków, Polska markwart.anna@gmail.com 